\title{
PERAN MODAL SOSIAL DALAM MENINGKATKAN KESEJAHTERAAN KELUARGA PERSPEKTIF MAQASHID SYARIAH (STUDI KASUS YAYASAN ROMBONG SEDEKAH JOMBANG)'
}

\author{
Sakethi Arrow Rulloh Saher
}

Mahasiswa Program Studi S1 Ekonomi Islam-Fakultas Ekonomi dan Bisnis-Universitas Airlangga Email: sakethi.arrow-13@feb.unair.ac.id

Irham Zaki

Departemen Ekonomi Syariah-Fakultas Ekonomi dan Bisnis-Universitas Airlangga Email: irham-z@feb.unair.ac.id

\begin{abstract}
This research is aimed to figure out and explain the role of social capital by seing from the correlation of networks, norm, and belief to improve the welfare of the community with maqashid syariah indicator. Qualitative research method and case study were used in this research as the strategy. This research possess an unit analysisof social capital and the improvement of social welfare which receive a loan with free riba from Rombong Sedekah Fondation. The data was collected by interviewing and observing to the direct object of the research. This research is interviewing staff on Rombong Sedekah Jombang Foundation and people who get donations from foundation. The qualitative explanatory was used as the techniques of analysis by explaining the results of the interviewers and of the direct observation. The result reveals that social capital with norms. Networks, and belief play a important role to improve the social welfare by seeing from maqashid syariah.
\end{abstract}

Keywords: social capital, foundation, welfare, and Maqashid Syariah

\section{PENDAHULUAN}

Modal sosial sering dikaitkan dengan keberhasilan dari sebuah masyarakat yang maju.Modal sosial dianggap memiliki hubungan yang erat dalam mencapai keberhasilan berbagai sektor kegiatan yang dilakukan oleh masyarakat seperti ekonomi, sosial, dan keadilam misalnya. Hal ini dikarenakan modal sosial memiliki unsur pokok kepercayaan, yang dalam pendapat Fukuyama (2002) dianggap sebagai tolak ukur paling baik dalam membangun sebuah masyarakat atau organisasi yang sehat.Selain itu, modal sosial dapat dikatakan sebagai suatu hubungan yang melandasi antar individu. Seperti yang kita tahu, manusia tidak dapat hidup sendiri dan senantiasa membutuhkan orang lain. Dalam bermasyarakat, manusia memerlukan kerjasama dan kebersamaan. Modal dalam modal sosial bukanlah sesuatu yang diartikan sebagai uang atau harta, namun lebih diartikan sebagai sesuatu yang penting dan dibutuhkan dalam hidup bermasyarakat.

Menurut Putnam dalam Field (2010:51) mendefinisikan modal Sosial sebagai bagian dari kehidupan yang berisi mengenai tiga hal, yaitu jaringan, norma, dan kepercayaan. Putnam beranggapan bahwa ketiga unsur diatas adalah unsurunsur modal sosial yang dibutuhkan pada masyarakat untuk mencapai suatu tujuan bersama.Berdasarkan ketiga unsur modal sosial, yakni norma, jaringan, dan trust, maka akanmenimbulkan adanya kontak sosial. Selain itu, Putnam jugamemperkenalkan perbedaan antara dua bentuk dasar modal sosial; 
Saher, et al/Jurnal Ekonomi Syariah Teori dan Terapan Vol. 5 No. 1 Januari 2018: 49-62; PERAN MODAL SOSIAL DALAM MENINGKATKAN KESEJAHTERAAN KELUARGA PERSPEKTIF MAQASHID SYARIAH (STUDI KASUS YAYASAN ROMBONG SEDEKAH JOMBANG)

menjembatani (inklusif) dan mengikat (eksklusif). Modal sosial bersifat mengikat (eksklusif) cenderung mendorong seseorang atau masyarakat bersifat homogenitas. Sedangkan modal sosial bersifat menjembatani (inklusif) cenderung menyatukan orang dari beragam ranah sosial.

Berbeda dengan pendapat Putnam, Bourdieu dalam Field (2010) berpendapat bahwa terdapat dimensi yang muncul pada unsur ekonomi, budaya, dan modal sosial sebagai bentuk dari keadaan sosial yang efektif sebagai symbol sosial. Konsep pada bourdieu mengatakan bahwa simbol sosial dapat menjadi usaha atau jalan keluar dalam penyelesaian masalah dalam tiap segi kehidupan. Perbedaan yang mencolok adalah bahwa Bourdieu tidak menganggap unsur trust karena menganggap unsur tersebut sudah mewakili bentuk dari salah satu upaya penyelesaian masalah dalam simbol sosial.

Sedangkan Fukuyama (2002) mengedepankan unsur trust dalam modal sosial dimana trust adalah fondasi utama dalam membangun sebuah hubungan dengan orang lain. Fukuyama dalam bukunya, Trust: Kebijakan Sosial dan PenciptaanKemakmuran menggolongkan kepercayaan pada dua jenis, yakni lowtrust yang terjadi pada masyarakat "familistik" seperti Cina, Perancis, Italia, dan Korea Selatan, dan high-trustpada masyarakat Jwpang dan Jerman.
Fukuyama dalam Hasbullah (2006: 108) beranggapan bahwa agama adalah salah satu sumber utama pembentukan modal sosial. Perkumpulan-perkumpulan keagamaan sangat potensial untuk menghadirkan dan membangun suatu bentuk dan ciri tertentu dari modal sosial. Ajaran agama merupakan salah satu sumber dari nilai dan norma yang dianut oleh seseorang atau golongan.

Di Indonesia misalnya, masyarakat akan memiliki tingkat kepercayaan yang tinggi terhadap ketua RT yang partisiatif dan mengikutsertakan warganya dalam setiap kegiatan yang ada. Pun Sebaliknya, tingkat kepercayaan bisa menururn jika seseorang yang mereka percaya akan membawa dampak baik justru melakukan suatu kesalahan. Contoh kasus yang pernah terjadi sekitar tahun 2015 adalah terungkapnya kasus korupsi dana zakat oleh pegawai negeri sipil (Sumber: Viva.co.id). Masih ada beberapa kasus korupsi serupa,yang membuat kepercayaan masyarakat pada suatu organisasi atau organ pemerintahan atau perangkat desa menjadi menurun. Hal itu bukan tanpa alasan, karena seringnya para elitlah yang menguasai berbagai kesempatan yang mengalir ke masyarakat seperti dana bantuan desa. Modal sosial yang dilakukan dengan baik tentu akan membawa dampak yang baik pula.

Dalam Islam, menurut Sanrego dan Taufia (2016) modal sosial terkait dengan pemberdayaan umat Islam yang telah 
Saher, et al/Jurnal Ekonomi Syariah Teori dan Terapan Vol. 5 No. 1 Januari 2018: 49-62; PERAN MODAL SOSIAL DALAM MENINGKATKAN KESEJAHTERAAN KELUARGA PERSPEKTIF MAQASHID SYARIAH (STUDI KASUS YAYASAN ROMBONG SEDEKAH JOMBANG)

diajarkan oleh Rasulullah. Dengan modal sosial yang kuat, maka akan relatif mudah membangun komunitas dan hubungan timbal balik serta alturism yang baik pada masyarakat.Dalam islam juga diajarkan mengenai semangat memberi dengan ikhlas yang merupakan unsur alturism dan resiproritas dari modal sosial. Namun dalam prakteknya masih ada beberapa yang jauh dari diidealkan oleh agama. Semisal di desa dengan penduduk yang miskin, inisiatif atau semangat untuk menolong masih sedikit. Pemberian bantuan hanya sekedar zakat konsumtif. Padahal, semangat untuk memberi ini tertuang beberapa kali dalam Al-quran. Masih ada beberapa golongan elit yang lebih suka untuk menikmati kelebihan harta yang mereka punya. Selain itu, tingkat kepercayan masyarakat sangat dipengaruhi dengan jaringan yang tercipta.Modal sosial pada Islam dapat dilihat pada surat Al-Hujurat: 10 seperti dibawah ini:

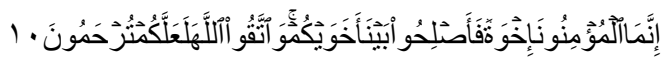

Artinya: Orang-orang beriman itu sesungguhnya bersaudara. Sebab itu damaikanlah (perbaikilah hubungan) antara kedua saudaramu itu dan takutlah terhadap Allah, supaya kamu mendapat rahmat.

Maksud dari potongan ayat di atas adalah bahwa hakekat dari seorang mukmin adalah menjaga tali silaturahmi antar sesama saudara. Jika dikaitkan dengan modal sosial, ayat di atas menekankan pentingnya hubungan kepercayaan yang melandasi jaringan atau tali silaturahmi dan berlandaskan norma-norma yang dianut serta menghasilkan hubungan timbal balik yang saling bermanfaat. Konsepmodal sosial dalam Surat Al-Hujarat dapat dijelaskn pada gambar berikut:

Hubungan masyarakat

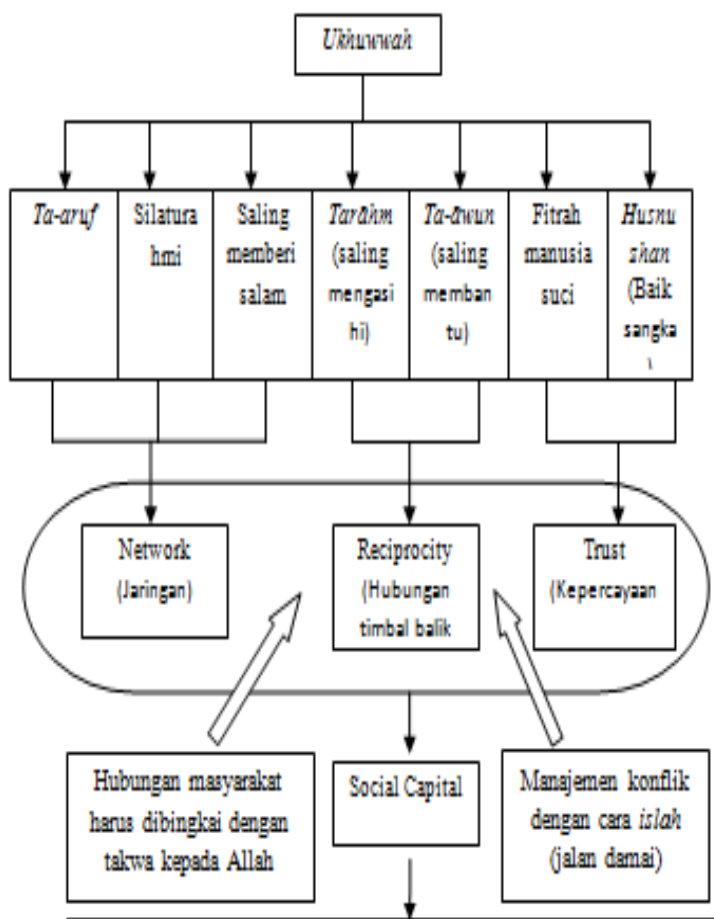

Rahmat Allah baik dalam skala milkro maupun makro. Dalam skalamikro diantaranya tercapainya Baldann Thayjibah wa Robbun Ghafur (Negeri yang tentram dan mendapat ridha Allah)

Gambar 1.1 Konsep Modal Sosial dari Surat Al-Hujurāt: 10

Sumber: Sanrego, Yulizar D, dan Moch.

Taufia ( 2016)

Gambar diatas adalah kesimpulan dari konsep modal sosial dari surat Al-Hujurat ayat 10. Dimana nilai-nilai Ukhuwwah saling mempengaruhi untuk terbentuknya modal sosial yang memiliki hubungan timbal balik dan berdampak pada nilai- 
Saher, et al/Jurnal Ekonomi Syariah Teori dan Terapan Vol. 5 No. 1 Januari 2018: 49-62; PERAN MODAL SOSIAL DALAM MENINGKATKAN KESEJAHTERAAN KELUARGA PERSPEKTIF MAQASHID SYARIAH (STUDI KASUS YAYASAN ROMBONG SEDEKAH JOMBANG)

nilai dalam menjalin hubungan dan manajemen konflik dengan cara yang damai.

$$
\text { Dari berbagai pandangan }
$$
mengenai modal sosial, muncul pertanyaan seperti bagaimana jika modal sosial tidak diterapkan dengan baik oleh masyarakat?Dampak apa yang akan terjadie Salah satu contoh penerapan modal sosial yang kurang adalah adanya tindak kriminalitas yang akhirnya membuat masyarakat menjadi kurang merasa aman saat berpergian. Kriminalitas seperti perampokan, begal, penipuan membuat kadar rasa aman seseorang menurun, yang artinya, tingkat trust seseorang juga ikut menurun. Selain itu, tindak kejahatan seperti kasus korupsi juga turut menurunkan tingkat masyarakat pada birokrasi atau pemerintahan yang ada.Hasbullah dalam bukunya yang berjudul Social Capital: Menuju Keunggulan Budaya Manusia Indonesia menjelaskan bahwa trust adalah bentuk paling sederhana pada modal sosial yang dapat tumbuh dan berkembang pada diri seseorang.

Dalam proses terjadinya,modal
sosial dapat tumbuh didaerah yang
cenderung homogen karena rasa
kebersamaan dan kepercayaan serta
kesamaan membuat masyarakat lebih
merasa dekat, sehingga nilai-nilai dari
modal sosial dapat tersalurkan dengan
baik.Suatu daerah atau golongan dengan
agama atau bahasa daerah yang sama
misalnya, dapat memiliki rasa

kebersamaan yang lebih baik dibandingan dengan daerah yang memiliki keberagaman yang banyak. Namun, keadaan yang cenderung homogen juga bisa menyebabkan modal sosial tidak tersalurkan dengan baik diluar lingkungan homogen tersebut. Hal ini dikarenakan adanya persepsi bahwa golongan mereka ynag paling baik, atau cenderung kurang bisa menerima pendapat atau keyakinan dari luar.

Pada pidato pengukuhan Djamaludin Ancok dalam Widayani dan Rachman (2013), modal sosial dapat memberikan tiga manfaat, yakni manfaat bagi masyarakat, manfaat bagi organisasi, dan manfaat bagi individu.Berdasarkan manfaat modal sosial yang kedua, yakni manfaat bagi organisasi, dapat dikatakanbahwa dengan adanya modal sosial, suatu organisasi, yayasan, ataupun komunitas dapat terbentuk.Hal ini dilandasi karena adanya keinginan untuk melakukan aktualisasi diri dan mewujudkan apa yang dicita-citakan bersama.

Dalam pelaksananannya, modal sosial dapat membentuk suatu modal komunitas. Namun bukan hanya modal sosial saja yang diperlukan untuk membentuk suatu modal komunitas. Diperlukan unsur lain seperti human capital, modal ekonomi, serta sumberdaya alam, yang saling mempengaruhi. Selain itu, terdapat faktor internal dan eksternal seperti agama, globalisasi, pendidikan, kepercayaan 
Saher, et al/Jurnal Ekonomi Syariah Teori dan Terapan Vol. 5 No. 1 Januari 2018: 49-62; PERAN MODAL SOSIAL DALAM MENINGKATKAN KESEJAHTERAAN KELUARGA PERSPEKTIF MAQASHID SYARIAH (STUDI KASUS YAYASAN ROMBONG SEDEKAH JOMBANG)

lokal, norma dan politik lokal yang ada pada suatu kelompok atau suatu masyarakat yang saling mengikat. Modal komunitas yang saling mempengaruhi terlihat seperti yang tertera pada gambar di bawah ini:

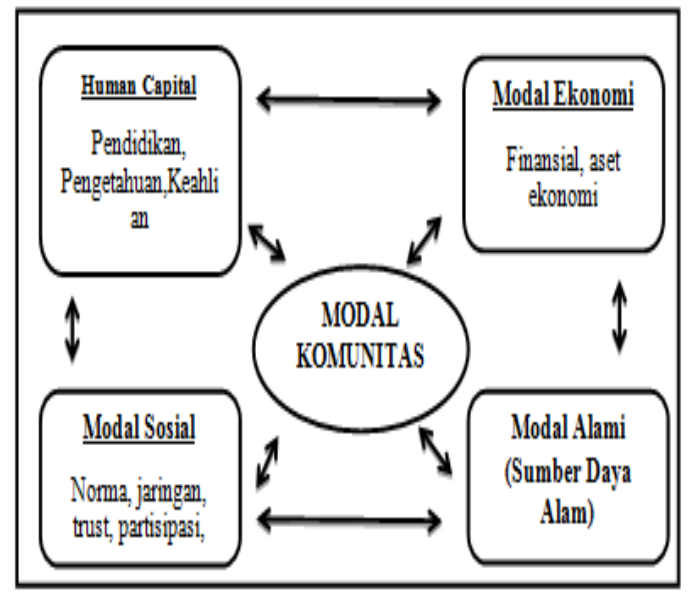

Gambar 1.2 Modal Komunitas

Sumber: Hasbullah, Jousairi. 2006

Ditinjau dari modal sosial, yayasan termasuk modal sosial pada dimensi struktural, dimana terdapat perangkat atau lembaga pada tingkat lokal yang mewadahi atau mendorong terjadinya kegiatan yang bermanfaat bagi masyarakat sekitar. Yayasan dirasa bisa menjadi solusi dalam menanggulangi tingkat kemiskinan Banyak komunitas yang akhirnya menjadi yayasan yang dapat terbentuk dari adanya modal sosial.Yayasan sebagai suatu Badan Hukum mampu dan berhak serta berwenang untuk melakukan tindakantindakan perdata. Selain itu, yayasanjuga dianggap sebagai sebuah kelompok yang berisikan seseorang atau masyarakat yang memiliki tujuanatau minat yang sama dalam hal sosial, kemanusiaan, dan kegamaan. Pada suatu yayasan tersebut, mereka memiliki kepercayaan, sumber daya yang ingin diwujudkan dalam bentuk suatu kegiatan yang sesuai dengan minat yayasan tersebut.

Simamora (2012), Dalam UndangUndang No 28 tahun 2004 mengenai tujuan yayasan yang diubah menjadi adanya tujuan sosal, keagamaan, dna kemanusiaan. Dalam pendirian yayasan, diperlukan adanya tiga organ inti, yakni: pembina, pengurus, pengawas dimana mereka memiliki tanggung jawab dan kewenangan dalam pengelolaan yayasan. Maka dari itu, dapat disimpulkan bahwa inti dari terciptanya suatu yayasan adalah karena terdapat kesamaan minat dan tujuan untuk memenuhi keinginan tersebut. Suatu yayasan dalam pendiriannya harus memiliki badan hukum dan memiliki aturan, dimana salah satunya terdapat pemisahan pada kekayaan pribadi karena yayasan bersifat amal.

Di Jombang terdapat yayasan yang awalnya berbentuk komunitas bernama Rombong Sedekah yang bertempat di Tambak Beras dan sudah berjalan hampir 3 tahun. Yayasan rombong sedekah dalam kegiatannya mendapat bantuan dari donatur dan masyarakat sekitar Yayasan tersebut. Program yang dilakukan berdasar nilainilai islami yang kental.Yayasan Rombong Sedekah memiliki 3 program, yaitu 
Saher, et al/Jurnal Ekonomi Syariah Teori dan Terapan Vol. 5 No. 1 Januari 2018: 49-62; PERAN MODAL SOSIAL DALAM MENINGKATKAN KESEJAHTERAAN KELUARGA PERSPEKTIF MAQASHID SYARIAH (STUDI KASUS YAYASAN ROMBONG SEDEKAH JOMBANG)

program memakmurkan masjid, program sosial dengan aksi pembangunan infrasturktur di desa terpencil, bedah rumah, bedah usaha, serta program yang ketiga adalah program ekonomi dengan aksi pinjaman bebas riba, dhuafa berdaya, serta wakaf produktif yang rencananya akan digunakan untuk pasar syariah pertama di Jombang.Yayasan. Semuanya disusun dan dikerjakan oleh para anggota dari Yayasan Rombong Sedekah, baik pegawai tetap maupun relawanyang memang memiliki niat ikhlas membantu.Karena sebaik- baiknya sutau golongan atau individu adalah mereka yang dapat mengajak pada kebaikan, seperti yang tertulis pada penggalan dari surat Al-Maidah :2 yang memiliki arti

"Dan tolong-menolonglah kamu dalam (mengerjakan) kebajikan dan takwa, dan jangan tolong-menolong dalam berbuat dosa dan pelanggaran. Dan bertakwalah kamu kepada Allah, sesungguhnya Allah amat berat siksaNya"

Dari ayat diatas dapat disimpulkan bahwa kita sebagai manusia harus saling tolong menolong kesasama. Hal ini nantinya dapat mempererat tali silaturahmi dan menumnuhkan sikap saling mengasihi dan berimbas pada adanya hubungan timbal balik dan munculnya kepercayaan yang tersirat dalam nilai nilai ukhuwwah.

Yang menjadi pertanyaan adalah, bagaimana modal sosial pada suatu yayasan dapat meningkatkan kesejahteraan masyarakat. Unsur atau halhal apa saja yang perlu diperhatikan atau dilakukan agar suatu masyarakat ikut tergerak dalam program yang telah diagendakan dan atau dari kegaitan tersebut, terdapat peningkatan kesejahteraan pada individu yang turut serta pada komunitas. Karena, agar seorang individu tergerak hatinya untuk ikut ambil andil dalam suatu yayasan, diperlukan adanya rasa simpati yang dapat berupa rasa kagum, perhatian, peduli, empati,penghargaan, rasa tanggung jawab, atau kepercayaan pada seseorang (Robison dalam Syahra: 2003). Maka dengan itu, berdasarkan latar belakang di atas, maka penelitian ini diberi judul Peran Modal Sosial Dalam Meningkatkan Kesejahteraan Masyarakat (Studi Kasus Yayasan Rombong Sedekah Jombang)

\section{Rumusan Masalah}

Pada penelitian ini, rumusan masalah sebagaimana dibawah ini:

Bagaimanakah peran modal sosial pada Yayasan Rombong Sedekah Jombang dalam meningkatkan kesejahteraan keluargat ditinjau dari perspektif maqashid syariah?

\section{Tujuan Penulisan}

Adapun tujuan penulisan dilihat dari rumusan masalah diatas adalah:

Mengetahui peran modal sosial pada Yayasan Rombong Sedekah 
Saher, et al/Jurnal Ekonomi Syariah Teori dan Terapan Vol. 5 No. 1 Januari 2018: 49-62; PERAN

MODAL SOSIAL DALAM MENINGKATKAN KESEJAHTERAAN KELUARGA PERSPEKTIF MAQASHID

SYARIAH (STUDI KASUS YAYASAN ROMBONG SEDEKAH JOMBANG)

Jombang dalam meningkatkan

kesejahteraan masyarakat

\section{Landasan Teori}

Banyak perbedaan batasan modal sosial menurut para ahli dalam menentukan komponen pembentuk modal sosial ynag paling penting. Beberapa penulis meneknankan pentingnya kepercayaan, beberapa mengatakan pentingan jaringan, namun Putnam berpendapat bahwa tiga komponen seperti norma, jaringan, dan kepercayaan sama sama pentingnya dan memiliki kontribusi masing masing. Di bawah ini adalah unsur-unsur pembentuk modal sosial menurut Putnam:

\section{a. Norma}

Norma dapat diartikan sebagai suatu pedoman yang digunakan oleh suatu golongan atau sesuatu yang berlaku, dan dihormati oleh suatu masyarakat.Norma sosial akan sangat berperan dalam mengontrol bentuk perilaku yang tumbuh dalam masyarakat (Hasbullah, 2006: 13). Norma biasanya mengandung sangsi sosial yang dapat mencegah individu untuk berbuat sesuatu yang menyimpang dari kebiasaan yang menyangkut dalam masyarakat. Norma sendiri dapat bermacam-macama jenisnya, seperti norma agama, norma susila, norma kesopanan, norma hukum, dan norma adat. Sebuah norma diperlukan agar terciptanya suatu masyarakat yang harmonis. Keberadaan norma dalam masyarakat bersifat memaksa individu atau suatu kelompok agar bertindak

sesuai dengan aturan sosial yang telah terbentuk sejak lama. Norma tidak boleh dilanggar. Siapa yang melanggar norma atau tidak bertingkah laku sesuai dengan ketentuan yang tercantum dalam norma, akan memperoleh hukuman. Norma merupakan hasil buatan manusia sebagai makhluk sosial.

\section{b. Jaringan}

Pertukaran dalam model jaringan, menurut Fukuyama dalam Handoyo (2013) bersifat timbal balik, tidak semata mata berdasarkan prinsip untung rugi. Hal ini terjadi karena pertukaran dalam jaringan berbasis norma bersama bersifat informal, tidak mengharapkan balasan langsung, tetapi mendambakan manfaat jangka panjang. Unsur jaringan pada modal sosial dibutuhkan untuk pertukaran informasi. Bagaimanakah hubungan antar anggota dalam suatu yayasan misalnmya, bagaimana mambangun hubungan dengan pihak lain juga termasuk dlam suatu jaringan. Dengan adanya jaringan, memungkinkan seseorang untuk bertukar informasi lebih cepat, sertaadanya 'channel' untuk memudahkan mereka dalam menjalankan suatu aktifitas. Seseorang fresh graduated dengan banyak teman yang bekerja diperusahaan lebih mudah mendapatkan info lowongan kerja terbaru lebih cepat dibandingkan dengan seseorang yang cenderung untuk menutup diri dari pergaulan. Suatu masyarakat dengan modal sosial yang tinggi cenderung memiliki tinggakt 
Saher, et al/Jurnal Ekonomi Syariah Teori dan Terapan Vol. 5 No. 1 Januari 2018: 49-62; PERAN MODAL SOSIAL DALAM MENINGKATKAN KESEJAHTERAAN KELUARGA PERSPEKTIF MAQASHID SYARIAH (STUDI KASUS YAYASAN ROMBONG SEDEKAH JOMBANG)

kejahatan yang rendah dikarenakan kuatnya hubungan yang terjalin antar individu. Dengan adanya jaringan pada modal sosial, dapat menjembatani tiap individu pada suatu daerah.

Modal sosial pada sistem jaringan sering diwarnai oleh adanya pertukaran kebaikan atau hubungan timbal balik yang dilandasi oleh rasa saling percaya dan membutuhkan. Pola pertukaran ini terjadi dalam jangka pendek dan jangka panjang dalam sebuah hubungan yang terjalin. Pada suatu kelompok yang memiliki pengelolaan organisasi lebih modern akan memiliki tingkat partisiapi yang tinggi dan rentang jaringan yang lebih luas. Suatu masyarakat yang memilikki hubungan timbal balik tanpa pamrih, atau dalam islam disebut dengan keikhlasan, akan melahirkan btingkat modal sosial yang tinggi yang muncul dalam bentuk keperdulian pada sesama dan lingkungan. Hasbullah :2006: 9) berpendapat bahwa jaringan yang muncul dan hubungan yang terjalin muncul karena terdapat prinsip kesukarelaan, kesamaan, kebebasan, dan keadaban.

\section{c. Trust}

Coleman (1988) menyatakan bahwa pentingnya sistem hubungan saling percayaan sangatlah penting dalam pembentukan modal sosial untuk hubungan kedepannya Sedangkan Putnam (1993) menganggap bahwa kepercayaan adalah salah satu sumber dari modal sosial yang dapat dapat mendorong kinerja ekonomi dan pemerintahan yang dinamis.Nahapiet and Ghoshal (1998) menekankan bahwa kepercayaan adalah kunci utama dalam hubungan dimensional dari modal sosial (Fu, 2004).

Fu dalam Hasbullah (2006: 12) membagi tiga tingkatan trust, yaitu pada tingkatan individual, tingkatan relasi sosial, dan pada tingkatan sistem sosial. Pada tingkatan individual, trust merupakan karateristik dari masing-masing individu, pada tingkatan hubungan sosial, trustmerupakan tindakan kolektif dalam sebuah kelompok untuk mencapai tujuan bersama. Sedangkan pada tingkatan sistem sosial, trust adalah nilai publik yang berkembang. Lantas dari mana datangnya trust tersebut? Jaringan menjadi sumber penting pada meningkatkan atau menurunnya rasa trust pada masing masing orang atau masyarakat. Tingkat kepercayaan seseorang pada individu lain menjadi menurut apabila orang tersebut sering berbohong, begitu pula sebaliknya.

Kepercayaan dibutuhkan dalam menjalin suatu hubungan, baik antar individu ataupun antar kelompok. Misalnya saja sebuah perusahaan yang ingin melakukan kontrak kerjasama dengan perusahaan lain, kepercayaan dibutuhkan agar kerjasama antar kedua perusahaan tersebut terjadi. Fukuyama dalam Fu (2004) mendefinisikan kepercayaan sebagai harapan yang timbul dalam masyarakat yang jujur, dan bersikap kooperatif, berdasarkan normanorma yang telah menjadi bagian 
Saher, et al/Jurnal Ekonomi Syariah Teori dan Terapan Vol. 5 No. 1 Januari 2018: 49-62; PERAN

MODAL SOSIAL DALAM MENINGKATKAN KESEJAHTERAAN KELUARGA PERSPEKTIF MAQASHID

SYARIAH (STUDI KASUS YAYASAN ROMBONG SEDEKAH JOMBANG)

masyarakat. Berikut adalah gambaran

pembentukan modal sosial.

\section{d. Kesejahteraan}

Menurut Undang-undang No 11 Tahun 2009, tentang Kesejahteraan Masyarakat, kesejahteraan masyarakat adalah kondisi terpenuhinya kebutuhan material, spiritual, dan sosial warga negara agar dapat hidup layak dan mampu mengembangkan diri, sehingga dapat melaksanakan fungsi sosialnya. Dari Undang-Undang di atas dapat kita cermati bahwa ukuran tingkat kesejahteraan dapat dinilai dari kemampuan seorang individu atau kelompok dalam usaha nya untuk memenuhi kebutuhan material dan spiritual nya.

Selain itu, Sherraden dalam Pusparini (2015) mengasumsikan bahwa jumlah pendapatan dan konsumsi rumah tangga merupakan gambaran yang tepat untuk dijadikan tolak ukur kesejahteraan. Kesejahteraan diasumsikan langsung dengan pendapatan dan konsumsi rumah tangga. Fokusnya adalah pada level konsumsi, termasuk jaminan kesehatan, perumahan, bantuan keuangan langsung, pendidikan, dan bidang kesejahteraan sosial lainnya.

Dalam sudut pandang konvensional, kesejahteraan dipandang hanya sebatas apabila seseorang terpenuhi secara matrealistis. Itulah yang terkadang menimbulkan pertanyaan, apakah kesejahteraan hanya dapat diukur secara nominal? Mengapa jika seseorang dikatakan sejahterah, beberapa dari mereka merasa gelisah dengan adanya tagihan-tagihan yang datang dari harta benda yang mereka miliki? Apakah rasa aman bukan termasuk bagian dari kesejahteraan? Seperti yang terkandung dalam UU No 6. Tahun 1974 tentang ketentuan-ketentuan pokok kesejahteraan sosial pasal 2 (1):

"Kesejahteraan sosial adalah suatu
tata kehidupan dan penghidupan
sosial materiil maupun spiritual yang
diliputi oleh rasa keselamatan,
kesusilaan, dan ketentraman lahir
batin, yang memungkinkan bagi
setiap warganegara untuk
mengadakan usaha pemenuhan
kebutuhan-kebutuhan yang jasmani,
rohanilah, dan sosial yang sebaik-
baiknya bagi diri sendiri, keluarga
serta masyarakat dengan
menjunjung tinggi hak-hak azasi
serta kewajiban manusia sesuai
dengan pancasila.
Kesejahteraan mempunyai
konotasi yang bermacam-macam. Orang awam mengartikan kesejahteraan sosial sebagai suatu situasi dan kondisi pribadi dan sosial yang menyenangkan. Ada ungkapan dalam bahasa jawa "gemah ripah loh jinawi, tata tentrem kerto raharjo", Adapula yang menggambarkan dengan kalimat "segala sesuatu yang serba beres", tidak ada hambatan, gangguan dan halangan, sehingga semuanya berjalan dengan lancar. Semua itu adalah ungkapan-ungkapan tentang arti sebuah kesejahteraan sosial yang hidup dalam masyarakat sebagi suatu kondisi kehidupan yang baik. 
Saher, et al/Jurnal Ekonomi Syariah Teori dan Terapan Vol. 5 No. 1 Januari 2018: 49-62; PERAN MODAL SOSIAL DALAM MENINGKATKAN KESEJAHTERAAN KELUARGA PERSPEKTIF MAQASHID SYARIAH (STUDI KASUS YAYASAN ROMBONG SEDEKAH JOMBANG)

Ghazali dalam Rahmawati (2012) memiliki konsep yang disebut "fungsi kesejahteraan sosial islami". Menurutnya, kesejahteraan (maslahah) darisuatu masyarakat tergantung kepada pencarian dan pemeliharaan lima tujuan dasar, yang pertama yakni agama, merupakan kumpulan akidah, ibadah, ketentuan dan hukum yang telah disyari'atkan Allah SWT untuk mengatur hubungan antara manusia dengan Allah, hubungan antara sebagian manusia dengan sebagian yang lainnya, yang kedua hidup atau jiwa. Islam mengatur eksistensi jiwa dengan mencipakan lembaga pernikahanuntuk mendapatkan keturunan. Islam juga melindungi dan menjamin eksistensi jiwa berupa kewajiban memenuhi apa yang menjadi kebutuhannya, sepertimakanan, minuman, pakaian, keluarga atau keturunan.

Selanjutnya harta atau kekayaan mengatur bagaimana memperoleh kekayaan dan mengusahakannya, seperti kewajiban mendapatkan rizki dan anjuran bermua'amalat, berniaga. Serta intelek atau akal melindungi akal dengan larangan mengkonsumsi narkoba atau segala hal yang memabukkan dan memberikan sanksi bagi yang mengkonsumsinya. Dan yang terakhir adalah keturunan. Al-Ghazali juga mencetuskan mengenai konsep kesejahteraan sosial atau utilitas(kebaikan bersama), yakni konsep yang mencakup aktifitas manusia dan yang memiliki kaitan erat antar individu. Ghazali juga mengidentifikasikan semua masalah, baik yang berupa masalih( utilitas, manfaat) maupun mafashid (disutilitas, kerusakan) dalam meningkatkan kesejahteraan sosial (Ghazali, dalam Pusparini, 2015).

la menitikberatkan bahwa sesuai tuntutan wahyu, tujuan utama kehidupan manusia adalah untuk mencapai kebaikan di dunia dan akhirat. Kunci dari terpenuhinya kelima hal diatas terletak pada terpenuhinya tiga hal kebutuhan manusia, yakni kebutuhan daruriyat seperti makanan, pakaian, rumah. Yang kedua adalah hajiyat dimana diperoleh kesenangan, dan yang terakhir adalah tahsiniyat atau sesuatu yang bersifat mewah.

\section{Metodologi Penelitian}

Penelitian ini menggunakan metode kualitatif. Metode kualitatif merupakan bagian dari proses pengetahuan yang dapat dianggap sebagai produk sosial dan juga proses sosial. Pengetahuan sebagai sebuah proses setidaknya memiliki tiga prinsip dasar yakni empirisisme yang berpangku pada fakta dan data, objektivitas dan kontrol (Singleton, dkk dalam Somantri , 2005).

Penelitian ini menggunakan pendekatan kualitatif dengan strategi studi kasus dan teknis analisis kualitatif eksplanatori karena berusaha menemukan jawaban antara sebab akibat yang ditimbulkan oleh peran modal sosial dalam meningkatkan kesejahteraan keluarga. Pengambilan data dilakukan dengan wawancara dan observasi kepada 6 orang informan. Yakni 
Saher, et al/Jurnal Ekonomi Syariah Teori dan Terapan Vol. 5 No. 1 Januari 2018: 49-62; PERAN MODAL SOSIAL DALAM MENINGKATKAN KESEJAHTERAAN KELUARGA PERSPEKTIF MAQASHID SYARIAH (STUDI KASUS YAYASAN ROMBONG SEDEKAH JOMBANG)

3 orang informan dari pihak yayasna dan

3 orang informan dari pedagang yang menerima bantuan dari yayasan. Bungin 2003: 20).

\section{Hasil dan Pembahasan}

Pada beberapa tabel di atas, terlihat bahwa modal sosial mampu meningkatkan kesejahteraan informan dalam tingkat kelvarga sejahterah tingkat II (KS II) hal ini karena selain kebutuhan dasar informan atau kesejahteraan tingkat I (KS I) terpenuhi, juga terjadi peningkatan kesejahteraan hampir pada setiap indikator maqashid syariah, khsusnya indikator agama, akal, dan harta dimana ketiga informan sama-sama merasakannya. Pada penelitian ini, terjadi dua tipe modal sosial yang saling mengikat dan mempengaruhi. Tipe modal sosial yang terjadi antar anggota yayasan adalah tipe Bonding. Bonding muncul antar individu yang sudah memiliki hubungan pertemanan yang lama atau sudah saling mengenal dalam waktu yang cukup lama seperti keluarga atau pertemanan. Hal itu terlihat dari jaringan yang terjadi antar sesama anggota yayasan. Perekrutan anggota yayasan lebih banyak didasarkan pada hubungan pertemanan yang sudah lama terjalin seperti antara informan 1 saat merekrut informan 2 dan informan 3. Sedangkan Pihak yayasan dengan pihak informan para pedagang terjadi modal sosial tipe bridging, yakni tipe yang muncul karena adanya koneksi atas dasar kesamaan dan atau memiliki kepentingan sehingga terjalinlah suatu kerjasama dan mengalami pertukaran informasi.

Dilihat dari aspek kepercayaan terdapat indikator harapan dan ketergantungan yang saling menguntungkan.antara kedua belah pihak. Dari pihak informan para penerima pinjaman, mereka memiliki harapan untuk dapat terus bekerja sama dengan pihak yayasan. Selain itu, mereka juga berharap agar yayasan dapat semakin berkembang, harapan yang tentu pihak yayasan juga ingin capai agar semakin banyak masyarakat yang mereka bantu.

Jika di hubungkan,ketiga unsur modal sosial yakni jaringan, norma, dan kepercayaan saling mempengaruhi terhadap kesejahteraan informan. Diawali dengan sebuah jaringan yang muncul satu sama lain dan semakin meluas jaringan yang dimili atau terajdi antar yayasan dan penerima donasi, serta ditaatinya norma-norma yang berlaku membuat hubungan kerja sama terjalin sangat baik. Serta adanya silaturahmi antar pihak yayasan dengan penerima bantuan, khusunya pinjaman bebas riba, serta pihak yayasna dengan donatur turut memperlebar jaringan kerjasama yang ada pada pihak yayasan. Dari jaringan yang muncul dan ditaatinya normanorma yang ada, memunculnkan rasa kepercayaan serta harapan-harapan para informan terhadap pihak yayasan. Munculnya rasa percaya pihak yayasan terhadap penerima pinjaman didasari oleh perasaan khusnudzhan bahwa penerima pinjaman dapat mengemban 
Saher, et al/Jurnal Ekonomi Syariah Teori dan Terapan Vol. 5 No. 1 Januari 2018: 49-62; PERAN

MODAL SOSIAL DALAM MENINGKATKAN KESEJAHTERAAN KELUARGA PERSPEKTIF MAQASHID

SYARIAH (STUDI KASUS YAYASAN ROMBONG SEDEKAH JOMBANG)

amanah. Dengan adanya jaringan, para

mereka

mampu

menghadapi

informan dapat menerima pinjaman

bebas riba dari Yayasan yang dampaknya dapat meningkatkan kesejahteraan mereka.

\section{Simpulan}

Modal sosial pada Yayasan Rombong Sedekah memiliki dampak dalam meningkatkan kesejahteraan masyarakat. Hal ini dikarenakan modal sosial yang ada tumbuh dan berjalan dengan baik antara kedua belah pihak, yakni yayasan dan penerima pinjaman bebas riba. Aspek modal sosial yang terjadi antara kedua belah adalah:

1. Jaringan: Meningkatnya jaringan pertemanan antar informan menyebabkan adanya pertukaran informasi dan hubungan timbal balik positif berupa meningkatnya kesejahteraan informan pedagang penerima bantuan pinjaman.

2. Norma: Kesepakatan yang diikuti dan ditaati dengan baik oleh kedua belah pihak menimbulkan tidak adanya perselisihan dan membuat informan mendapatkan bantuan pinjaman dua kali dari pihak yayasan. Bantuan tersebut sangat membantu informan pedagang untuk meningtkan aktifitas jual beli mereka dan berimbas pada peningkatan pendapatan dan kesejahteraan mereka.

3. Kepercayaan: Pihak yayasan mempercayai bahwa penerima bantuan adalah orang yang amanah dan menimbulkan harapan bagi penerima bantuan bahwa mereka dapat lebih meningatkan kesejahteraan mereka, permasalahan yang ada dengan baik.

Dari ketiga aspek modal sosial yang ada, terlihat bahwa selain jaringan, norma, dan kepercayaan, muncul adanya hubungan timbal balik dan pertukaran informasi pada aspek jaringan dan timbulnya harapan-harapan bagi pihak yayasan dan penerima bantuan. Selain itu, pihak penerima bantuan mengalami pengingkatan kesejahteraan dan terpenuhi kebutuhan pad tingkat dharuriyyah dan dan beberapa aspek indicator hajiyah.

\section{Daftar Pustaka}

Agustin, Atut Frida dkk. 2013. Identifikasi Modal Sosial Pada Program Pemberdayaan Masyarakat Miskin Melalui Dana Zakat, Infaq dan Sedekah. IQTISHODUNA, Vol. 9, No : 1-8.

Bourdieu, Pierre. 1990. The logic of Practice. Atandford University Press: California. Hal: 54

Bungin, Burhan. 2003. Analisis Data Penelitian Kualitatif: Pemahaman Filosofis dan Metodologis ke Arah Penguasaan Model Aplikasi. Jakarta: PT. Raja Grafindo Persada

Cahyono, Ardian. 2012. Peran Modal Sosial Dalam Peningkatan Kesejahteraan Masyarakat Petani Tembakau di Kabupaten Wonosobo. UNISSULA, Vol. 1, No. 1, Desember: 131-144.

Field, John. 2010. Modal Sosial. Bantul: Kreasi Wacana. 
Saher, et al/Jurnal Ekonomi Syariah Teori dan Terapan Vol. 5 No. 1 Januari 2018: 49-62; PERAN

MODAL SOSIAL DALAM MENINGKATKAN KESEJAHTERAAN KELUARGA PERSPEKTIF MAQASHID

SYARIAH (STUDI KASUS YAYASAN ROMBONG SEDEKAH JOMBANG)

Fu, Qianhong. 2004. Trust, Social Capital, and Organizational Effectiveness.Faculty of the Virginia Polytechnic Institute and State University, 22 April: 1-34.

Fukuyama, Francis. Trust: Kebijakan Sosial dan Penciptaan Kemakmuran. 2002. Yogyakarta: CV. Qalam Yogyakarta.

Furbey, Robert, et al. 2006. Faith as social capital. Sheffield Hallam University, Maret: $1-61$.

Handoyo, Eko. 2013. Kontribusi Modal Sosial Dalam Meningkatkan Kesejahteraan Pedagang Kaki Lima Pascarelokasi. Jurnal UNNES, Jurnal Komunitas 5 (2) (2013): 252266

Hasbullah, Jousairi. 2006. Social Capital: Menuju Keunggulan Budaya Manusia. Indonesia. Jakarta: MR- United Press.

Kara, Muslimin. 2012. Pemikiran Al-Syatibi Tentang Maslahah dan Implementasinya Dalam Pengembangan Ekonomi Syariah. ASSETS, Vol. 2 No. 2, 2012: 173- 184

Kearns, Ade. 2004. Social Capital, Regeneration \& Urban Policy. CNR PaperVol.15, April 2004:1-39

Mahalli, Ahmad Mudjab dan Ahmad Rodli Hasbullah. 2004. Hadist-hadist Muttafaq 'Alaih: Bagian Munakahat dan Mu'amalat. Jakarta: Prenada Media Group.

Mulyono,Sutrisno Purwohadi. BentukBentuk Penerapan Norma Hukum Adat
Dalam Kehidupan Masyarakat Di Jawa Tengah. Jurnal Media Hukum, Edisi 252.

Muflikhati, dkk. 2010. Kondisi Sosial Ekonomi dan Tingkat Kesejahteraan Keluarga: Kasus di Wilayah Pesisisr Jawa Barat.Jurnal IIm. \& Kons, vol 3, No 1

Nasution, dkk. 2014. Dampak Modal Sosial Terhadap Kesejahteraan Rumah Tangga Pedesaan di Indonesia. MIMBAR, Vol.30, No.2, Desember: 137-148.

Piere Bourdeiau. 1990. The Logic of Practice. Atanford University Presss: California, Hal:54

Pusparini, Dwi Martini. 2015. Konsep Kesejahteraan Dalam Ekonomi Islam: Perspektif Maqasid Asy-Syari'ah. Jurnal UII Yogyakarta, Vol.1 No.1, Juni: 45-59.

Rahmawati, lilik. 2012. Konsep Ekonomi AlGhazali. Maliyah. Vol.2, No. 1, Juni: 329341.

Sampe, Evi, dkk. Pengembangan Jejaring Organisasi Yayasan Sangatta Baru (YSB) untuk Meningkatkan Kesejahteraan Sosial Masyarakat. Jurnal Administrasi Publik, Vo;. 2, No. 3: 471- 477.

Sanrego, Yulizar D, dan Moch. Taufiq. 2016. Fiqih Tamkin (Fikih Pemberdayaan). Jakarta: Qisthi Press.

Simamora, Sogar. 2012. Karateristik, Pengelolaan, dan Pemeriksaan Badan Hukum Yayasan di Indonesia. Jurnal Rechts Vinding, Vol. 1, No. 2, Agustus: 175186. 
Sodiq, Amirus. 2015. Konsep Kesejahteraan

Dalam Islam. EQUILIBRIUM, Vol. 3, No.2,

Desember.

Somantri, Gumilar Rusliwa. Memahami Metode Kualitatif. 2005. MAKARA, SOSIAL HUMANIORA, VOL. 9, NO. 2,

Suarez, Christoper. 2005. Civil Society adn the Dangers of Social Capital. Vol. 1, 18 Maret, 2005: 1-10.

Syahra, Rusydi. 2003. Modal Sosial: Konsep dan Aplikasi. Jurnal Masyarakat dan Budaya, Vol. 5, No. 1: 1-20.

Siisiäinen, Marti. 2000. Two Concepts of Social Capital: Capital: Bourdieu vs. Putnam. Jurnal dipresentasikan pada Konferensi Internasional ISTR yang keempat "The Third Sector: For What and for Whom?".Trinity College, Dublin, Ireland : July 5-8, 2000

http://nasional.news.viva.co.id/news/read /583838-empat-pns-jadi-tersangka-korupsidana-zakat. Diakses pada tanggal 07 April, 2017, pukul 01.23 WIB.

Widayani, Retno, \& Rachman. 2013. Studi Tentang Kemunculan Modal Sosial. Jurnal Kebijakan dan Administrasi Publik, Vol. 17, No. 2: 65-75. 